\title{
Surface Mixed Layer Profile of Physical and Biogeochemical Variables in the Subpolar North-West and -East Atlantic Ocean: A Data-Model Comparison Study
}

\author{
Nsikak U. Benson ${ }^{*}$, Francis E. Asuquo ${ }^{2}$, Oladele O. Osibanjo ${ }^{3}$, Usoro M. Etesin ${ }^{4}$, \\ Adebusayo E. Adedapo ${ }^{1}$ \\ ${ }^{1}$ Environmental Chemistry Unit, Department of Chemistry, Covenant University, Ota, Nigeria \\ ${ }^{2}$ Institute of Oceanography, Department of Physical Oceanography, University of Calabar, Calabar, Nigeria \\ ${ }^{3}$ Department of Chemistry, University of Ibadan, Ibadan, Nigeria \\ ${ }^{4}$ Department of Chemistry, Akwalbom State University, Mkpat-Enin, Nigeria \\ Email: ${ }^{*}$ benson@covenantuniversity.edu.ng
}

Received 11 October 2014; revised 8 November 2014; accepted 4 December 2014

Copyright (C) 2015 by authors and Scientific Research Publishing Inc.

This work is licensed under the Creative Commons Attribution International License (CC BY).

http://creativecommons.org/licenses/by/4.0/

(c) (i) Open Access

\section{Abstract}

This paper presents a study of physical and biogeochemical variables using numerical model and mixed layer oceanographic data from a 2 - 3 year in situ measurements in the Northwestern and Northeastern sites of the Atlantic Ocean. Model outputs are presented and indicated that very good estimates may be obtained. The outputs showed considerable agreement in reproducing seasonal distributions of $p \mathrm{CO}_{2}, p \mathrm{CO}_{2}-T, p \mathrm{CO}_{2}$-nonT, mixed layer temperature, and chlorophyll- $a$ in both winter and summer, and therefore provide useful physical and theoretical understanding of their biogeochemistry. The model $p \mathrm{CO}_{2}$ indicated a distinct temporal variability with seasonal changes coinciding with the change in sea surface temperature. It also provides an agreement that there is a strong seasonal cycle of mixed layer parameters filliped by nonthermal and physical factors. As an outgrowth of this work, the $\mathrm{pCO}_{2}$ model outputs affirm the North Atlantic Ocean capacity as an important oceanographic sink for anthropogenic carbon dioxide.

\section{Keywords}

Mixed Layer Profile, $\mathrm{pCO}_{2}$, Ocean Circulation Model, Model Validation, North Atlantic Ocean

\footnotetext{
${ }^{*}$ Corresponding author.
}

How to cite this paper: Benson, N.U., et al. (2015) Surface Mixed Layer Profile of Physical and Biogeochemical Variables in the Subpolar North-West and -East Atlantic Ocean: A Data-Model Comparison Study. Open Journal of Marine Science, 5, 33-44. http://dx.doi.org/10.4236/ojms.2015.51004 


\section{Introduction}

In recent years, several scientists and groups of researchers have carried out in situ measurements of surface microlayer (SML) and mixed layer (MLD) physical and biogeochemical parameters covering large ocean areas and span multiple of years in an effort to help us better understand the ocean processes. Although a long term autonomous in situ ocean monitoring has successfully taken root at some locations, however, there are quasi-continuous direct measurements of ocean parameters carried out at a large number of monitoring stations around the global oceans that seek to provide us with spatial and temporal oceanographic data. Quite a number of these stations are deep-ocean observatories sited in waters off the continental shelf and are capable of producing quality datasets of essential climate and ocean variables such as temperature, $\mathrm{pH}$, salinity, oxygen, carbon dioxide and mesozooplankton, and biogeochemical variables including nitrate, chlorophyll and phosphate from the SML through the MLD to the ocean floor. In recent years, scientists have employed measured data from these observatories (buoys, ships, satellite) in ocean researches including modeling applications in developing a better understanding of the underlying biogeochemical processes and the impacts of our changing global oceans [1] [2]-[5].

In the past years, several numerical models have been developed and are employed in understanding and producing nowcast, forecast and hindcast simulations of the biogeochemical patterns in the ocean [6]-[9]. These coupled physical-biogeochemical models are efficient, fast, compact and powerful scientific tools that are employed in understanding the past, present and futuristic changes in ocean variables and the climate. Modeling the oceanic response typically involves the interaction between physical (stratification, temperature, salinity, mixing, solar radiation, etc.), chemical (dissolved inorganic carbon (DIC), total alkalinity, particulate inorganic carbon (PIC), $\mathrm{pH}$, oxygen, phosphate, silica and iron), and biological processes (zooplankton, phytoplankton and dissolved organic carbon (DOC), dissolved organic matter (DOM) and particulate organic matter (POM)) [9]-[11]. Moreover, in recent years research efforts have been focused on the incorporation of observed data into numerical models for operational estimation and forecasting of the state of the ocean. This process is known as data assimilation. Several marine biogeochemical modeling data assimilation studies have been reported [6] [7] [12][14]. Also, observed oceanographic data can be employed to validate a biogeochemical model output.

In this paper observed data from two oceanographic observatories in the Northeastern Porcupine Abyssal Plain (PAP) and Northwestern K1 Central Labrador Sea (K1 CELAS) (Figure 1) were used to compare the qualitative agreement or departure signatures produced by a physical-biogeochemical-ecosystem model in order to provide a better view of the variability and processes of the physical and biogeochemical properties at these North Atlantic Ocean sites. An attempt is therefore made to investigate how well the model can capture in situ observations as well as deconvolute associated physical and biological forcings. The imperativeness of accurately capturing both the $p \mathrm{CO}_{2}-T$ (thermal) and $p \mathrm{CO}_{2}$-nonT (nonthermal) composites of $p \mathrm{CO}_{2}$ to further understand the biogeochemical dynamics of the $p \mathrm{CO}_{2}$ cycle in the ocean has been outlined by [15]. Characteristically, the $p \mathrm{CO}_{2}$ cycle is a combination of the patterns of temperature $\left(p \mathrm{CO}_{2}-T\right)$ and the non-thermal or biological $\left(p \mathrm{CO}_{2}\right.$-nonT) cycles. Both cycles are usually in antiphase and are governed by distinct physical and biogeochemical factors. Seawater $p \mathrm{CO}_{2}$ could be influenced by factors such as change of sea surface temperature (SST), deep convective mixing with carbon dioxide enriched subsurface waters, and consumption by marine biota linked to the availability of surface nutrients [9] [16] [17].

\section{Study Area, Data and Methods}

\subsection{Source of Observed Data}

The details of the sampling strategy, analytical methods, data quality control and calibration procedures employed for taking the diverse set of biogeochemical and physical measurements and recovered observational data at the KI CELAS and PAP observatories (Figure 1) have been reported by [16] [17] and also available on the EuroSITES data documentation (http://www.eurosites.info/).

\subsection{The Physical-Biogeochemical-Ecosystem Ocean Model}

The numerical model used for this research is the MIT Ocean General Circulation Model (MITgcm) regionally configured for the North Atlantic Ocean with computational domain $20^{\circ} \mathrm{S} 81.5^{\circ} \mathrm{N}$, and a horizontal resolution of $0.5^{\circ}$ longitude and $0.5^{\circ}$ latitude. The MITgcm is a physical-biogeochemical-ecosystem model designed for study of the atmosphere, ocean, and climate. Details of this model have been described in previous papers [9] [18], and the principal features of the physical part of the model are presented in Table 1. 


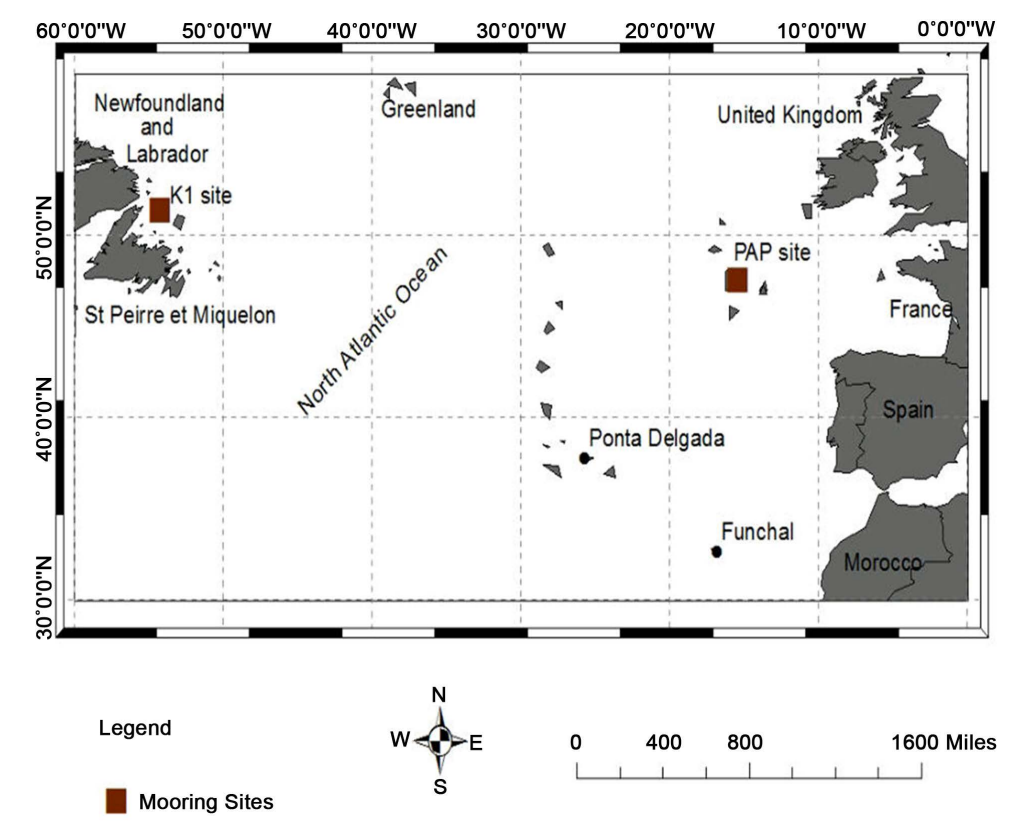

Figure 1. Map of the North Atlantic Ocean showing the Porcupine Abyssal Plain (PAP) and Central Labrador Sea sites.

Table 1. Key features of the physical model.

\begin{tabular}{lll}
\hline Physical Model & MIT Ocean General Circulation Model \\
\hline Computational domain & & $20^{\circ} \mathrm{S}$ and $81.5^{\circ} \mathrm{N}$ \\
Resolution & Longitude & $0.5^{\circ}$ \\
& Latitude & $0.5^{\circ}$ \\
& Vertical & $\begin{array}{l}23 \text { vertical levels with a resolution of } 10 \mathrm{~m} \text { thickness at the surface, } \\
\text { increasing to } 500 \mathrm{~m} \text { thickness for depths greater than } 2200 \mathrm{~m}\end{array}$ \\
& $\begin{array}{l}\text { Daily fields from NCEP/NCAR Reanalysis I for 1992-2006. Sea surface temperatures (SSTs) } \\
\text { are relaxed (two week timescale) to 1992-2006 satellite-based estimates [19]. } \\
\text { Gent-McWilliams eddy parameterization [20] }\end{array}$ \\
Surface forcing & Nonlocal K-Profile parameterisation (KPP) boundary layer mixing scheme [21]. \\
\hline
\end{tabular}

The model incorporates nutrient cycling using an ecosystem model of intermediate complexity [10] and carbonate chemistry cycling [22] that models a pelagic ecosystem with one zooplankton class and two phytoplankton classes (diatoms and small phytoplankton) [10] [18]. The atmospheric $p \mathrm{CO}_{2}$ forcing in the model is from Mauna Loa Observations [23] and takes into account the annual seasonal $p \mathrm{CO}_{2}$ cycle. A schematic presentation of the ecosystem part of the MITgcm is as illustrated (Figure 2).

\section{Results and Discussion}

\subsection{Depth Profile of $\mathrm{pCO}_{2}$, Associated Composites, Physical and Biogeochemical Parameters at PAP Observatory}

In this section, the mixed layer depth profile of partial pressure of $\mathrm{CO}_{2}\left(p \mathrm{CO}_{2}\right)$, thermal $\left(p \mathrm{CO}_{2}-T\right)$ and nonthermal ( $\left.p \mathrm{CO}_{2}-n o n T\right)$ composites of $p \mathrm{CO}_{2}$, physical and biogeochemical parameters such as temperature, chlorophyll-a and salinity are estimated with the primary objective of reenacting scenarios that would have been obtainable in the absence of in situ measurements. Therefore, the following diagrams depict the characteristic model simulations of $p \mathrm{CO}_{2}, p \mathrm{CO}_{2}-T, p \mathrm{CO}_{2}-n o n T$, MLD temperature, chl- $a$, and salinity profiles at the subpolar NE Atlantic Ocean time series PAP location (Figures 3-8). 


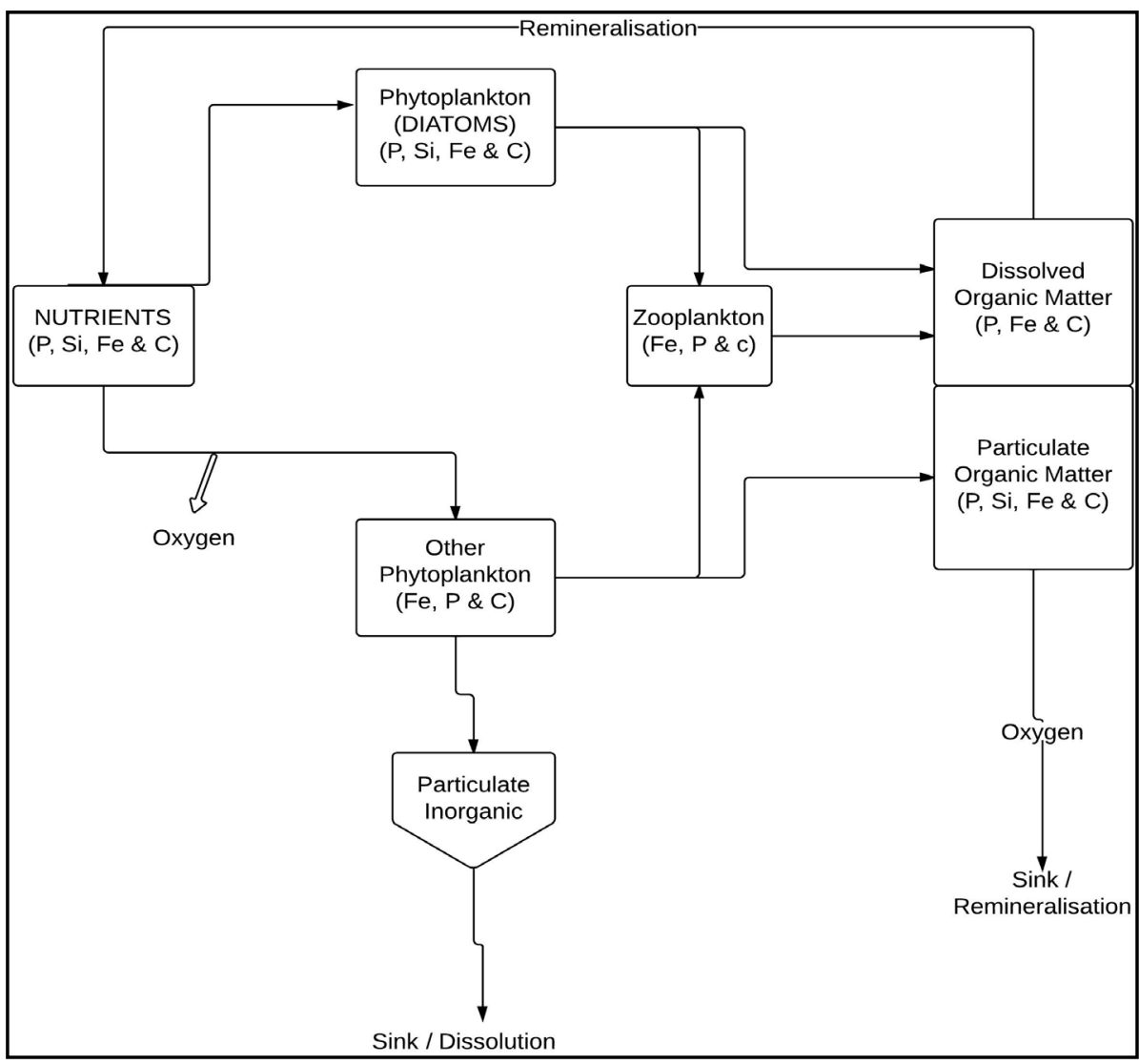

Figure 2. Schematic diagram of ecosystem model showing the nutrients cycling by two classes of phytoplankton, one class of zooplankton, and two pools dissolved organic matter (DOM) and particulate organic matter (POM). Ecosystem model adapted from [10].

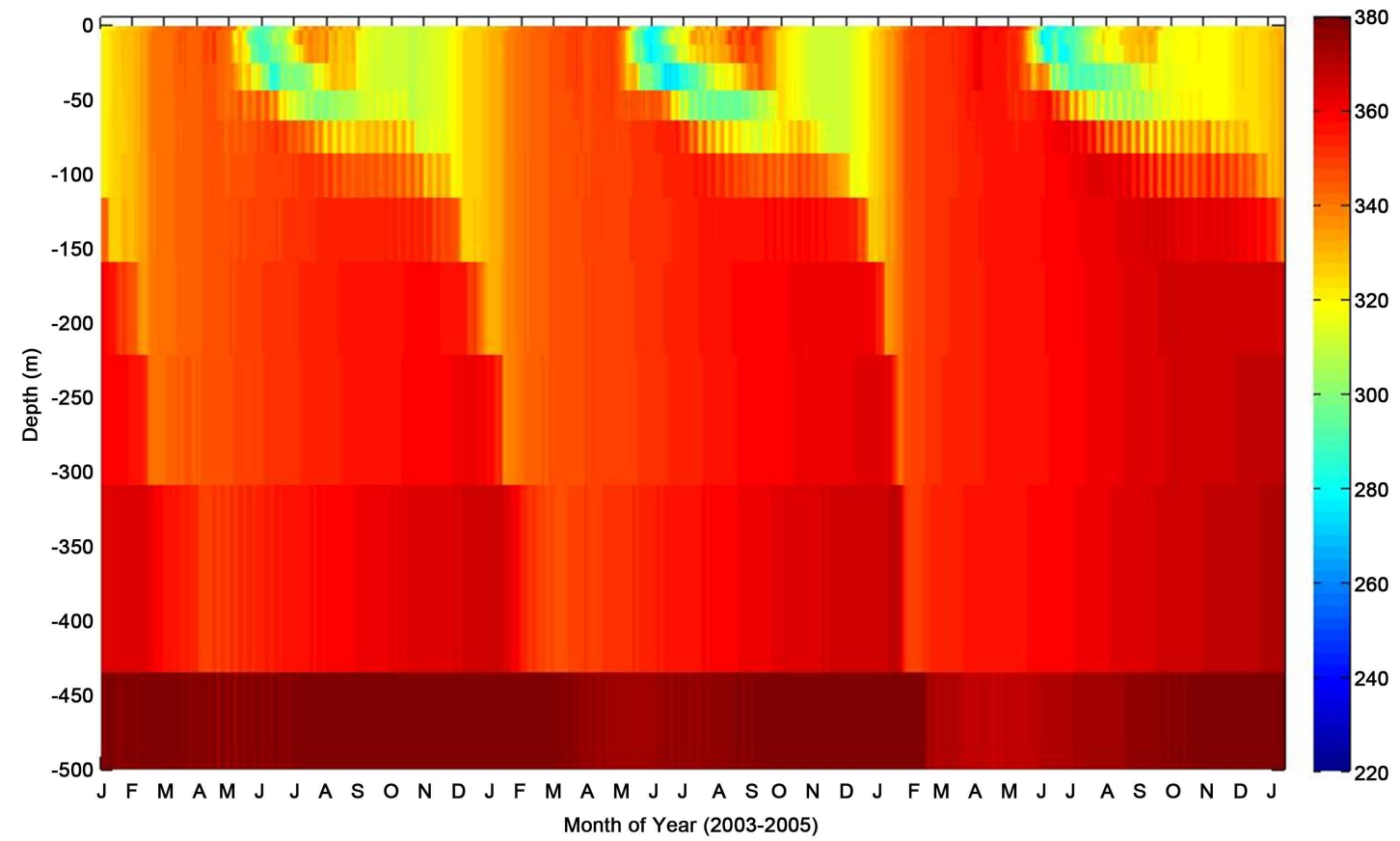

Figure 3. Mixed layer depth profile of $p \mathrm{CO}_{2}$ during period of consecutive deployments at the PAP site. 
N. U. Benson et al.

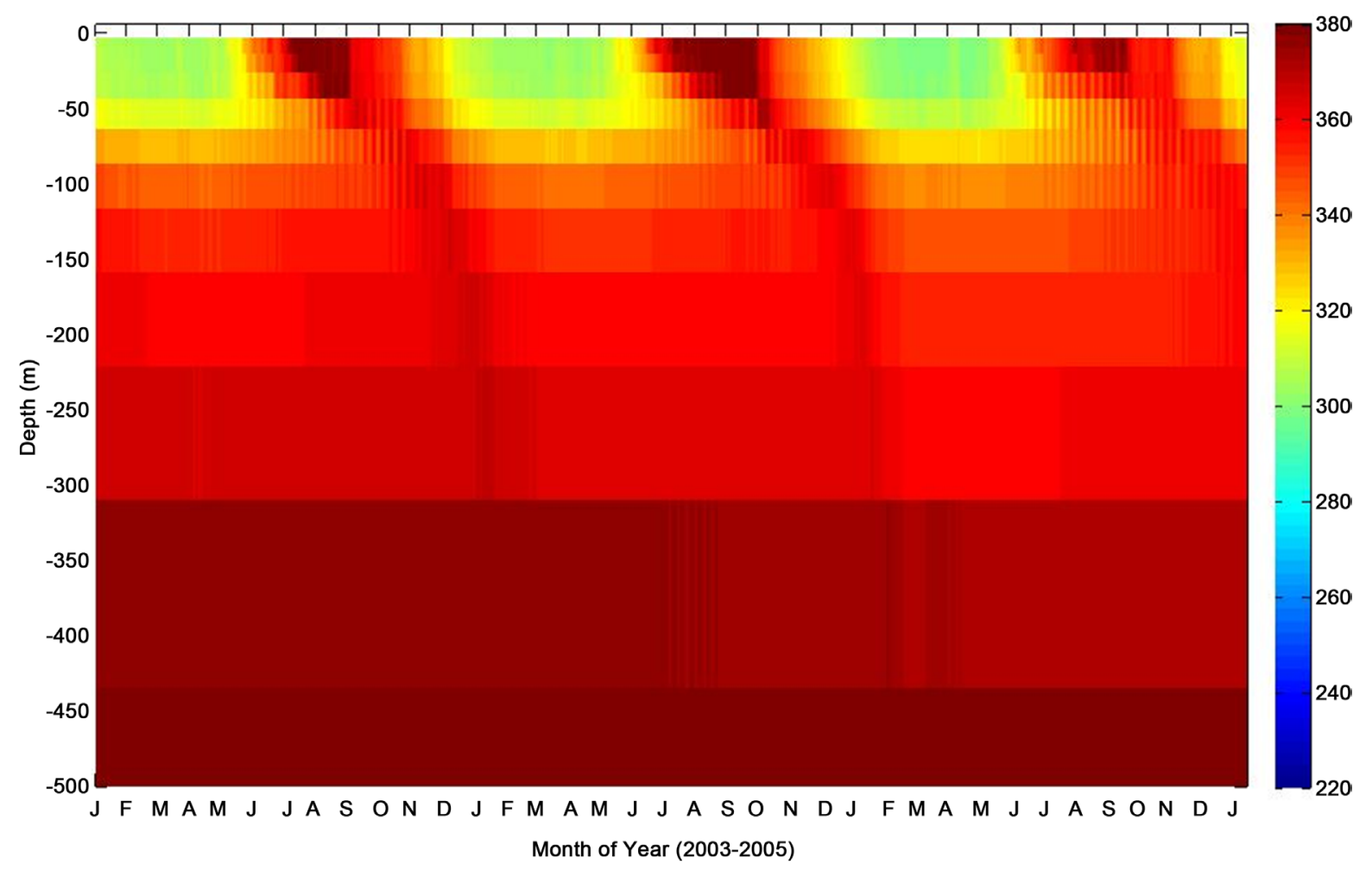

Figure 4. Mixed layer depth profile of thermal $p \mathrm{CO}_{2}\left(p \mathrm{CO}_{2}-T\right)$ during period of consecutive deployments at the PAP site.

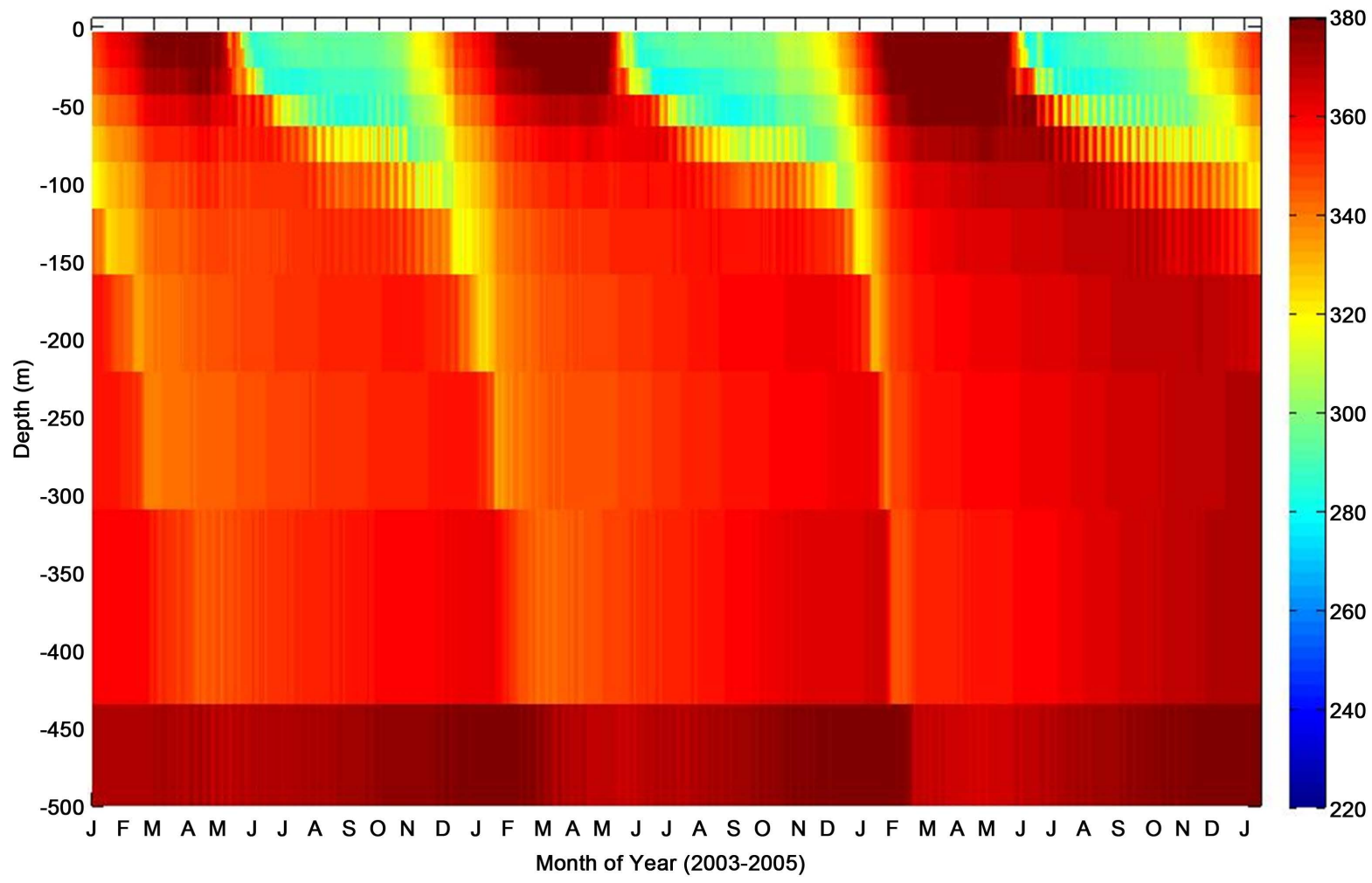

Figure 5. Mixed layer depth profile of nonthermal $p \mathrm{CO}_{2}\left(p \mathrm{CO}_{2}\right.$-nonT) during period of consecutive deployments at the PAP site. 


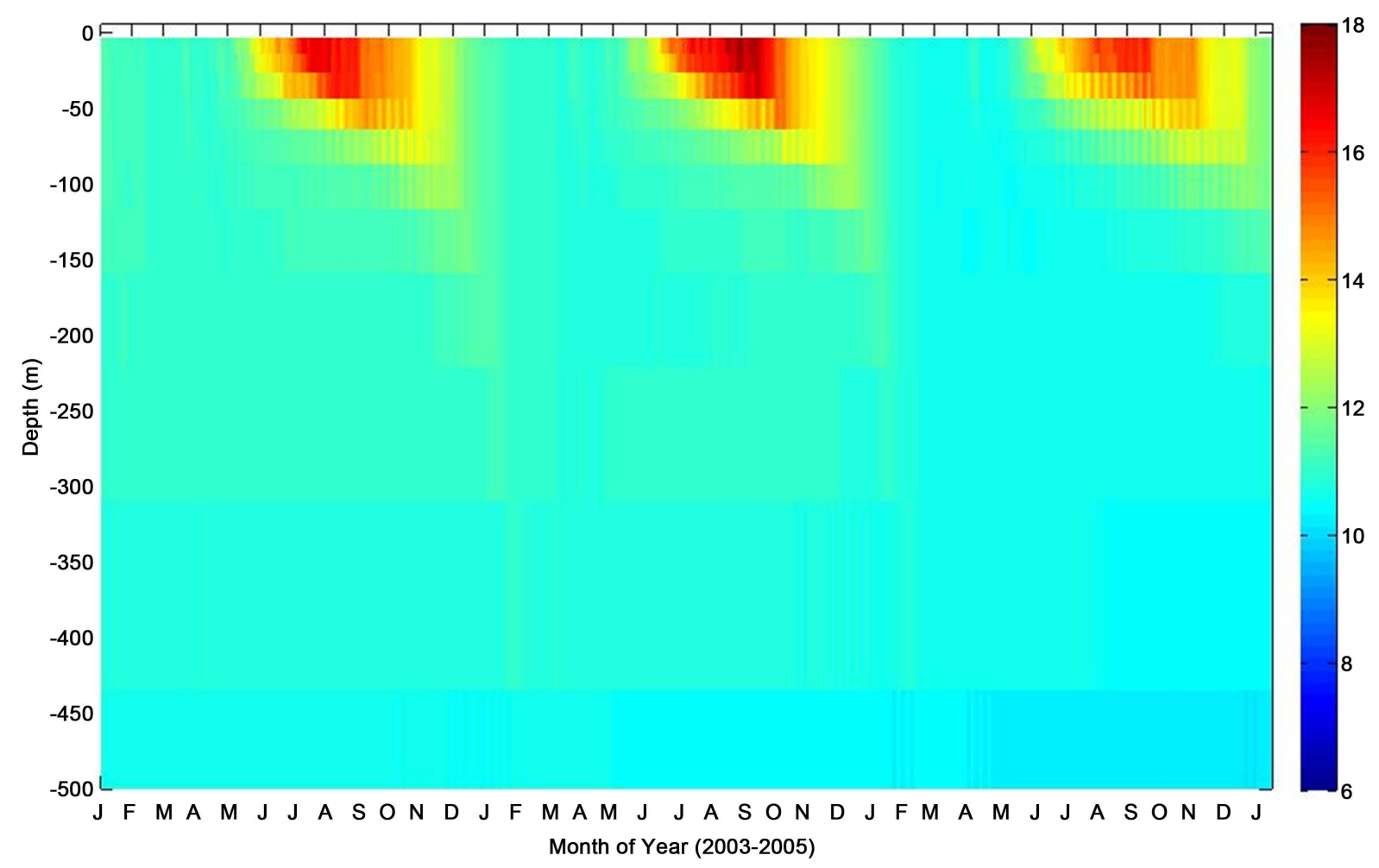

Figure 6. Mixed layer depth temperature profile corresponding to period of consecutive deployments at the PAP site.

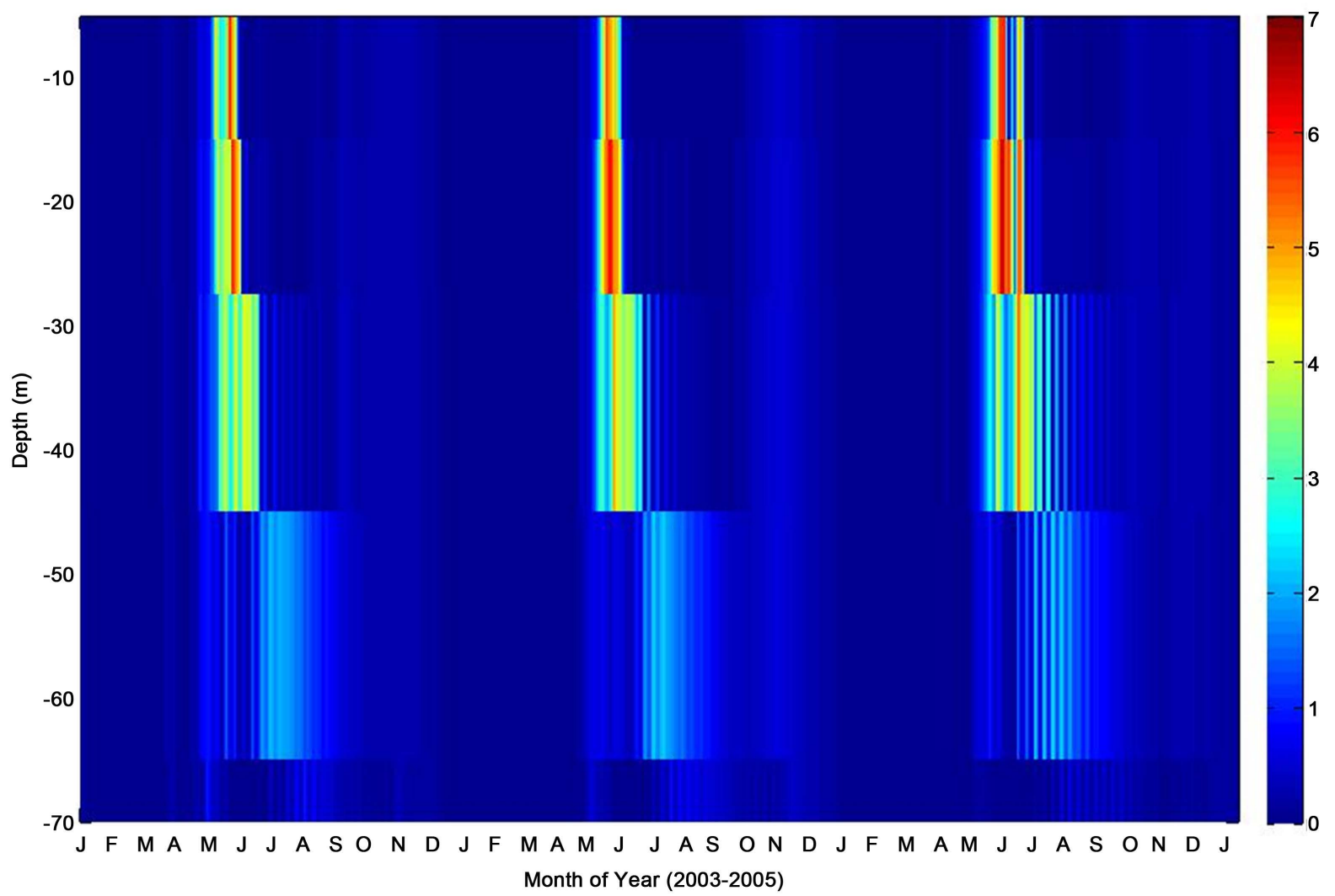

Figure 7. Mixed layer depth chlorophyll- $a$ profile corresponding to period of consecutive deployments at the PAP site. 


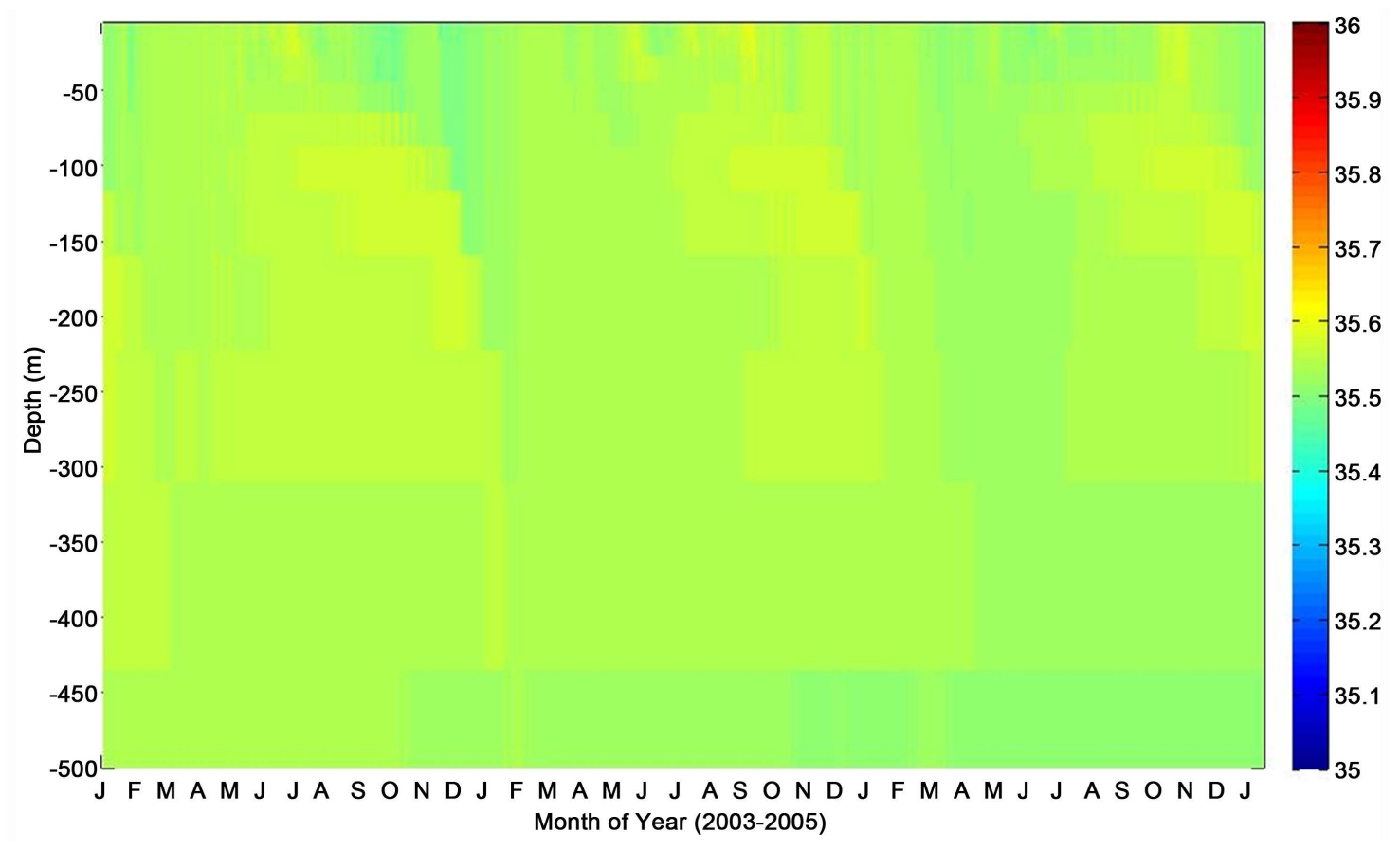

Figure 8. Salinity depth profile corresponding to period of deployments at the PAP site.

The model mixed layer $p \mathrm{CO}_{2}$ (Figure 3) indicated a distinct temporal variability as the season changes coinciding with the change in sea surface temperature. Also illustrated in Figure 3 is the fact that the model $p \mathrm{CO}_{2}$ generally showed relatively high $p \mathrm{CO}_{2}$ with increasing depth of the ocean. The oceanic $p \mathrm{CO}_{2}$ during the summertime as expected was characteristically low at the surface mixed layer and may be attributed to stratification of the mixed layer depth, and relatively higher during the wintertime following deep convective mixing. Although displaying characteristics associated with increased biological activity, the mesopelagic level of $p \mathrm{CO}_{2}$ was relatively high. This appears to be as a result of a possible nutrient drawdown and other inorganic and organic carbon producing processes such as respiration, remineralisation, among others. The thermal $\left(p \mathrm{CO}_{2}-T\right)$ and nonthermal ( $p \mathrm{CO}_{2}$-nonT) composites of $p \mathrm{CO}_{2}$ (Figure 4 and Figure 5), further elucidate the driving forces governing the seasonal variability of $p \mathrm{CO}_{2}$. The $p \mathrm{CO}_{2}$-T showed a characteristic maximum $p \mathrm{CO}_{2}$ levels in summer and minimum in winter, while the $p \mathrm{CO}_{2}$-nonT component indicated a marked seasonal summertime minimum to late wintertime maximum with phenomenally high $p \mathrm{CO}_{2}$ during the springtime. The enhanced surface mixed layer $p \mathrm{CO}_{2}$ is indicative of possible spring bloom estimation or entrainment of dissolved carbon and nutrients rich water to the upper mixed layer. In an oceanographic region considered as a perennial sink for atmospheric $\mathrm{CO}_{2}$, mixing processes are capable of entraining $\mathrm{CO}_{2}$ - enriched bottom mixed layer seawaters into the upper euphotic layer, thereby resulting in enhanced $p \mathrm{CO}_{2}$.

The model mixed layer temperature profile suggests that the ocean system at the PAP site had a temperature-induced (warming) stratified mixed layer during summertime that tended to extend into early fall, followed by a rapid wind-driven mixing of subsurface waters into the mixed layers through the wintertime (Figure 6). However, this is followed by a re-stratification period, which starts as early as May and lasts the summertime following the warming of the ocean. Warming of ocean euphotic zone has been reported to induce stratification. This oceanic process is reportedly governed by a combination of positive physical forcing fueled by temperature changes [24]. The profile estimated by the model showed a season-dependent change in mixed layer temperature, with sea surface temperature indicating relatively high estimates during the summertime to early fall (Figure 6). This is expected but however, the marked decline in temperature down the mixed layer especially along stratified gradient in the summer months, separating the specific thermoclines of the oceanic layer is worthy of note.

Model output for the PAP site indicated that maximum levels of chlorophyll- $a$ concentration (maximum levels of phytoplankton) were observed during the late spring through early summer. This is in fair agreement with the observed PAP data, which showed a characteristic regional summertime maximum, wintertime minimum variability (Figure 7). It is worthy of note that the model output indicated chlorophyll- $a$ concentrations 
from the surface microlayer extending to about $45 \mathrm{~m}$ depth, with moderately elevated concentrations simulated within the $0-25 \mathrm{~m}$ depth. This enhanced chlorophyll- $a$ concentration might have been filliped by entrenchment of nutrients, and could have coincided with a period of shallower mixed layer, which later disappeared following the outset of a possible deep mixing period. According to [16], this is partly due to dilution in addition to possible export. Also, model oceanic mixed layer salinity profile corresponding to the period of deployments at the PAP observatory, clearly shows slight to moderate seasonal variability in salinity gradient throughout the period (Figure 8). Based on monthly averages, the salinity distribution could have been influenced by convective currents in the region. Salinity changes are also closely associated with rainfall events. However, much variability in seawater salinity could simply be attributed to physical processes rather than other events, and is not caused by a salinity change in the water itself.

\subsection{Depth Profiles of $p \mathrm{CO}_{2}$, Associated Composites, Physical and Biogeochemical Parameters at K1 Central Labrador Sea}

In this section, the profiles of $p \mathrm{CO}_{2}, p \mathrm{CO}_{2}-T, p \mathrm{CO}_{2}$-nonT, mixed layer temperature, and chlorophyll- $a$ are simulated depth wise using the MITgcm numerical model and observed oceanographic data obtained at the $\mathrm{K} 1$ site. Figures 9-13 show model simulations of $p \mathrm{CO}_{2}, p \mathrm{CO}_{2}-T, p \mathrm{CO}_{2}$-nonT, MLD temperature and chl- $a$ depth integrated profiles respectively at the subpolar NW KI Central Labrador Sea time series site. Model integrated $p \mathrm{CO}_{2}$ simulation (Figure 9) indicates a general trend towards higher $p \mathrm{CO}_{2}$ at low temperatures and vice versa. This is consistent with observational data summertime $p \mathrm{CO}_{2}$ minimum and wintertime maximum.

The ocean system at the K1 Central Labrador Sea site as simulated witnessed a temperature-induced stratified mixed layer during the summertime and tended to extend deeper down the subsurface as fall sets in. This was followed by a possible wind-driven mixing of subsurface waters into the mixed layers through the wintertime. The convective entrainment of subsurface nutrients and export production in the model shows a clear increase in seawater surface $p \mathrm{CO}_{2}$. This estimate is also consistent with the observed data. However, as depicted in the plot, a re-stratification period appears to have preceded the convective mixing of subsurface seawater [24].

The oceanic $p \mathrm{CO}_{2}-T$ model (Figure 10) depicted a stratified mixed layer that spans all year round. Characteristically, summertime high $p \mathrm{CO}_{2}$ coincided with increase in temperature, while wintertime relatively low temperatures were marked by low $p \mathrm{CO}_{2}$ at the seawater surface. This is expected because warm summer surface waters are known to promote enhanced $p \mathrm{CO}_{2}$. In the winter, mixed layer tends to cool and deepens (Figure 12). This is attributed to net heat lost at the ocean surface and mixed-layer bottom [25]. During this time, intense

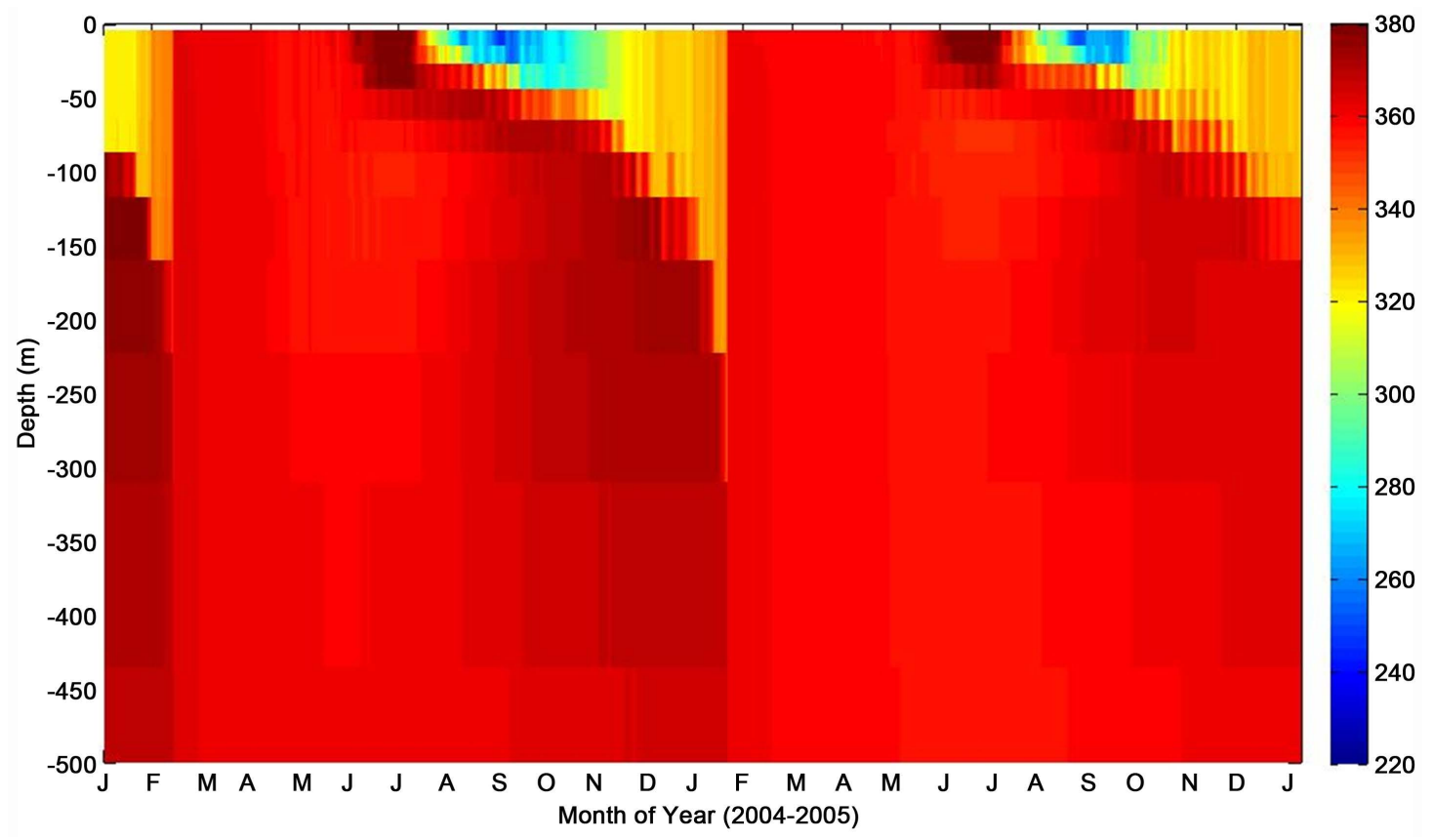

Figure 9. Depth profile of $p \mathrm{CO}_{2}$ during consecutive deployments at $\mathrm{K} 1 \mathrm{Central}$ Labrador Sea time series site. 


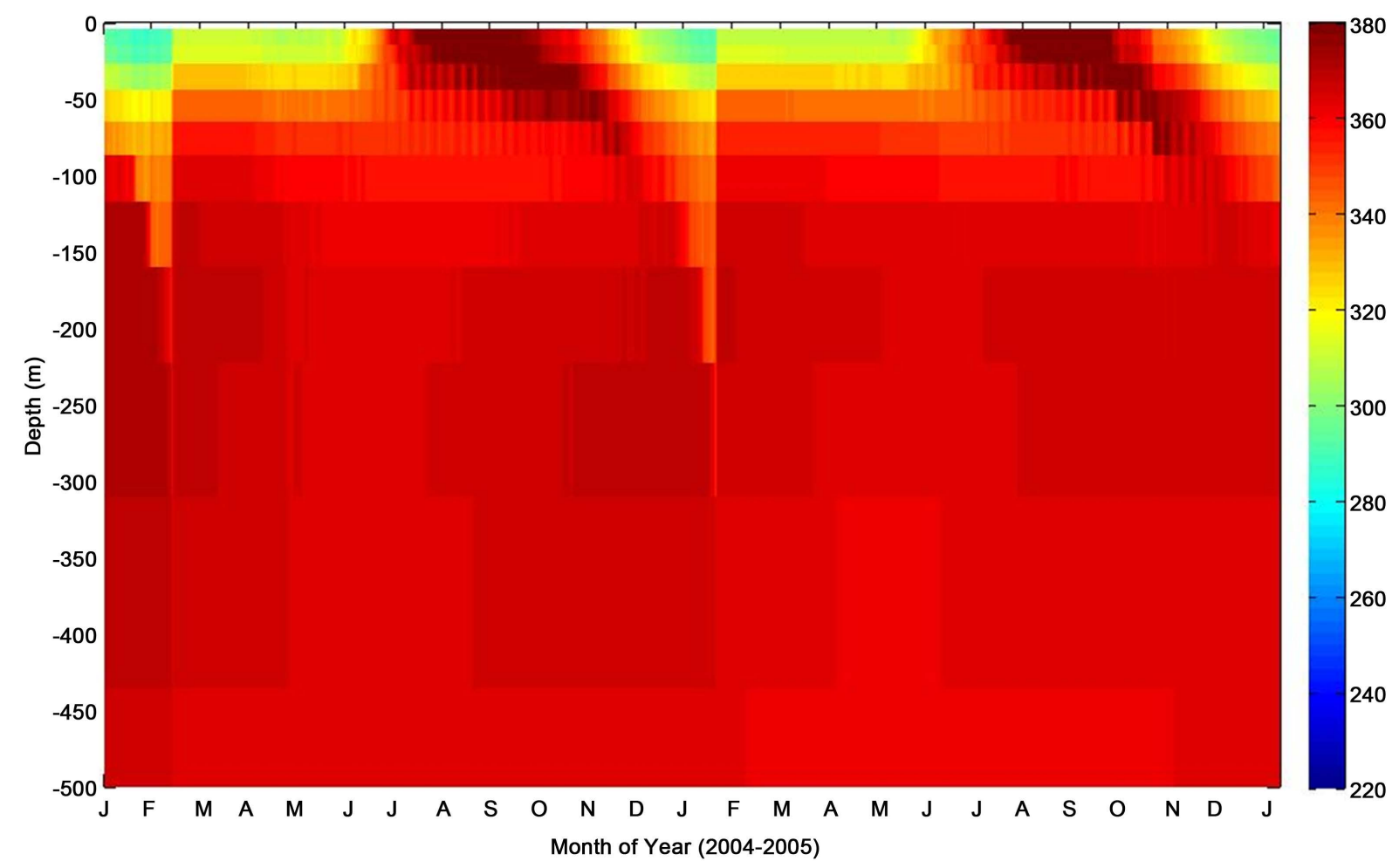

Figure 10. Depth profile of thermal $p \mathrm{CO}_{2}\left(p \mathrm{CO}_{2}-T\right)$ at K1 Central Labrador Sea site.

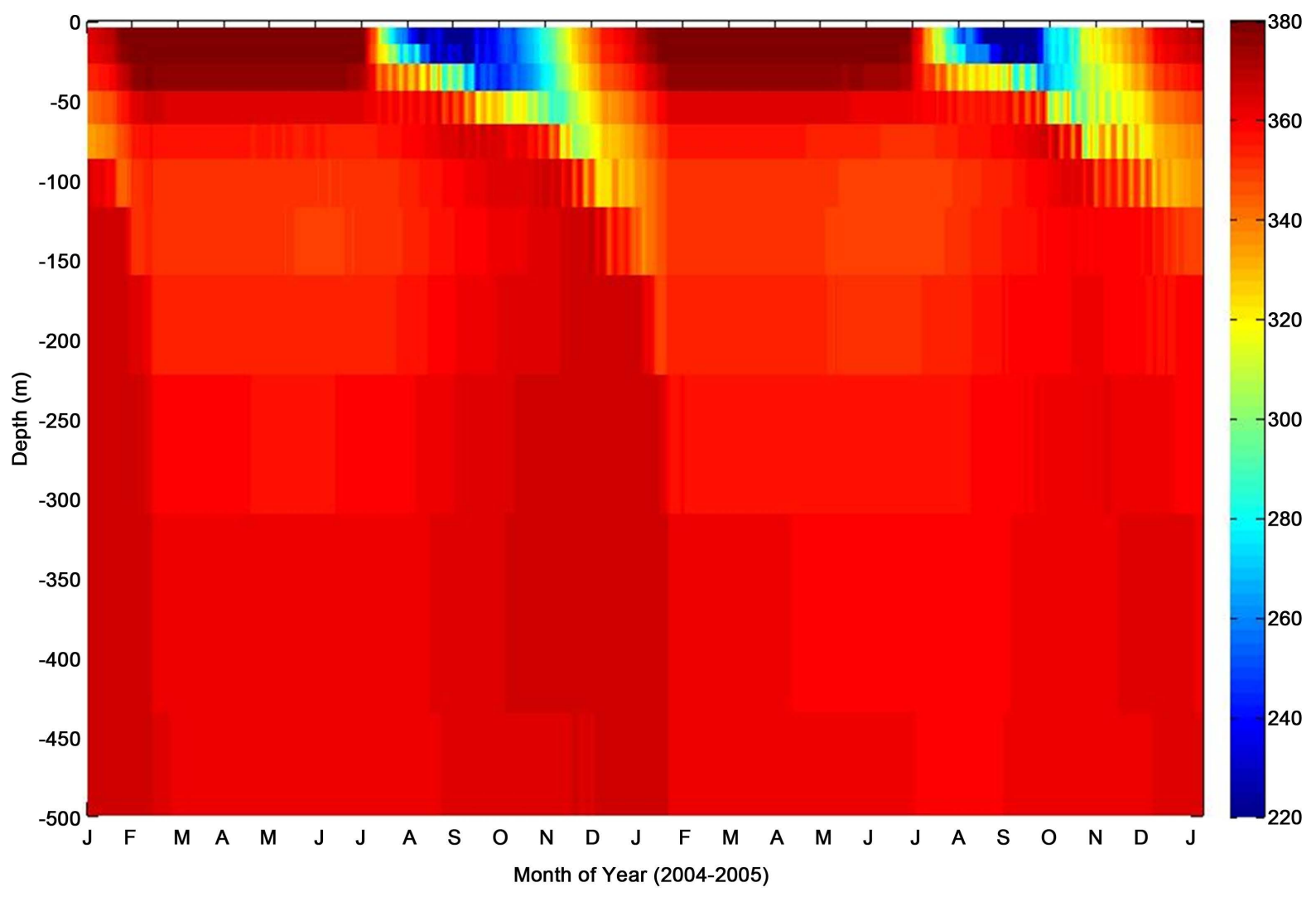

Figure 11. Depth profile of nonthermal $p \mathrm{CO}_{2}\left(p \mathrm{CO}_{2}\right.$-nonT $)$ at $\mathrm{K} 1$ Central Labrador Sea site. 


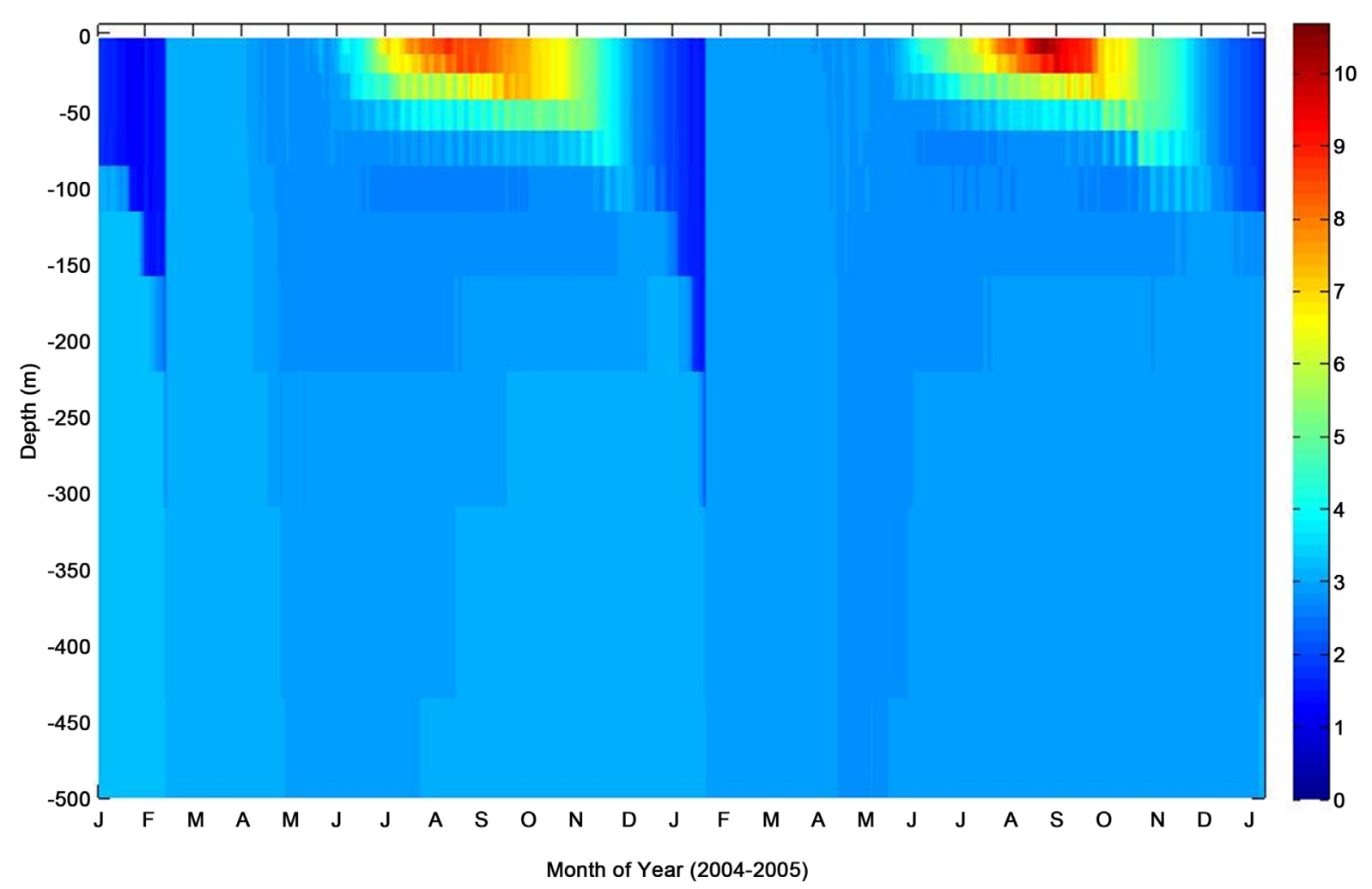

Figure 12. Mixed layer temperature profile at K1 Central Labrador Sea time series site.

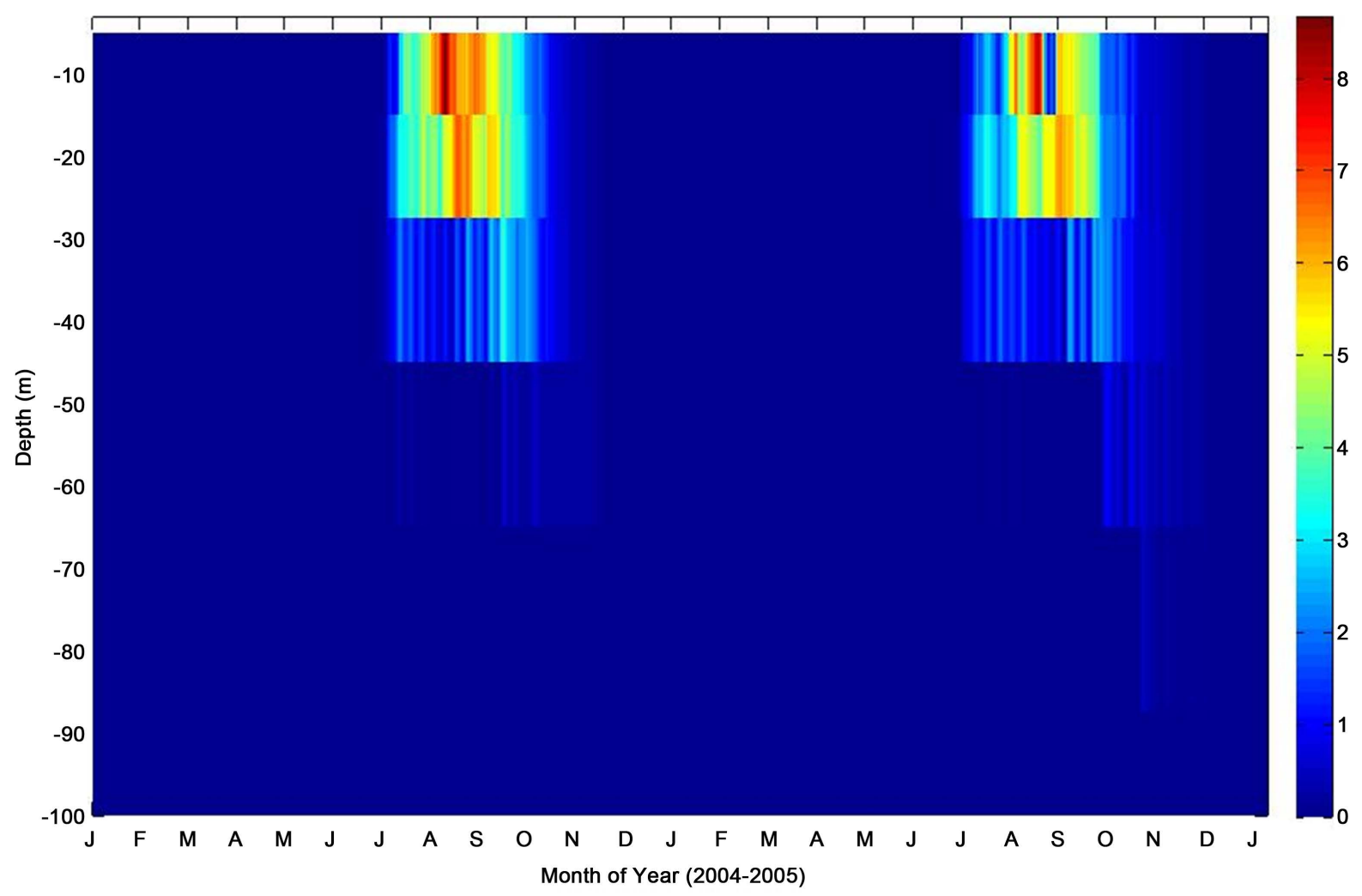

Figure 13. Model chlorophyll- $a$ profile at K1 Central Labrador Sea time series site. 
thermal convection might be responsible for the mixed-layer deepening. Model chlorophyll- $a$ profile at the K1 indicated significant biological signal during the summer months with intense productivity extending down to about $25 \mathrm{~m}$ depth. Therefore, increase in mixed layer chlorophyll- $a$ concentrations coincided with summertime. This is expected because biological production reduces $p \mathrm{CO}_{2}$. The model output generally showed a characteristic regional interannual variability with a summertime maximum and wintertime minimum chlorophyll- $a$ concentration (Figure 13). This work has provided a means of simulating parameters that could reflects oceanographic observations, determines the approximated values of the poorly known parameters, and provides insight into which physico-biogeochemical parameters are constrained by the model [26]-[28].

\section{Conclusion}

In the present paper, a numerical model has been applied to capture in situ observations and was found to yield satisfactory model outputs over time and depth of two North Atlantic oceanographic sites. For most of the ocean parameters considered, it has been shown that the model outputs indicated high consistency of surface mixed layer physico-biogeochemical properties with seasonal and depth changes. Model outputs showed considerable agreement in reproducing seasonal distributions of $p \mathrm{CO}_{2}, p \mathrm{CO}_{2}-T, p \mathrm{CO}_{2}$-nonT, mixed layer temperature, and chlorophyll- $a$ in both winter and summer. The outputs therefore provide useful physical and theoretical understanding of the biogeochemistry of each variable, and the consistency of the model trends appear to conform with observed data within the observation uncertainties at the two oceanographic sites. As an outgrowth of this work, the $\mathrm{pCO}_{2}$ model outputs affirm the North Atlantic Ocean capacity as an important oceanographic sink for anthropogenic carbon dioxide.

\section{Acknowledgements}

The EuroSITES Project data was used for this research. The contributions of the principal investigator and other scientists involved in the PAP project are acknowledged. The first author is particularly thankful to Prof. G. A. McKinley for guidance. The authors would like to thank anonymous reviewers for their comments and suggestions that much improved the original manuscript.

\section{References}

[1] Matear, R.J. and Jones, E. (2010) Marine Biogeochemical Modelling and Data Assimilation. Global Ocean Data Assimilation Experiment Special Volume.

[2] Bates, N.R., Pequignet, A.C. and Sabine, C.L. (2006) Ocean Carbon Cycling in the Indian Ocean: 1. Spatiotemporal Variability of Inorganic Carbon and Air-Sea $\mathrm{CO}_{2}$ Gas Exchange. Global Biogeochemical Cycles, 20, GB3020. http://dx.doi.org/10.1029/2005GB002491

[3] Bates, N.R., Pequignet, A.C. and Sabine, C.L. (2006) Ocean Carbon Cycling in the Indian Ocean: 2. Estimates of Net Community Production. Global Biogeochemical Cycles, 20, GB3021. http://dx.doi.org/10.1029/2005GB002492

[4] Sabine, C.L., Wanninkhof, R., Key, R.M., Goyet, C. and Millero, F.J. (2000) Seasonal $\mathrm{CO}_{2}$ Fluxes in the Tropical and Subtropical Indian Ocean. Marine Chemistry, 72, 33-53. http://dx.doi.org/10.1016/S0304-4203(00)00064-5

[5] Sharada, M.K., Swathi, P.S., Yajnik, K.S. and Devasena, C.K. (2008) Role of Biology in the Air-Sea Carbon Flux in the Bay of Bengal and Arabian Sea. Journal of Earth System Science, 117, 429-447. http://dx.doi.org/10.1007/s12040-008-0043-9

[6] Brasseur, P., Gruber, N., Barciela, R., Brander, K., Doron, M., El Moussaoui, A., Hobday, A.J., Huret, M., Kremeur, A.-S., Lehodey, P., Matear, R., Moulin, C., Murtugudde, R., Senina, I. and Svendsen, E. (2009) Integrating Biogeochemistry and Ecology into Ocean Data Assimilation Systems. Oceanography, 22, 206-215. http://dx.doi.org/10.5670/oceanog.2009.80

[7] Doron, M., Brasseur, P., Brankart, J.-M., Losa, S.N. and Melet, A. (2013) Stochastic Estimation of Biogeochemical Parameters from Globcolour Ocean Colour Satellite Data in a North Atlantic 3D Ocean Coupled Physical-Biogeochemical Model. Journal of Marine Systems, 117-118, 81-95. http://dx.doi.org/10.1016/j.jmarsys.2013.02.007

[8] Ford, D.A., Edwards, K.P., Lea, D., Barciela, R.M., Martin, M.J. and Demaria, J. (2012) Assimilating GlobColour Ocean Colour Data into a Pre-Operational Physical-Biogeochemical Model. Ocean Science, 8, 751-771. http://dx.doi.org/10.5194/os-8-751-2012

[9] Ullman, D., McKinley, G.A., Bennington, V. and Dutkiewicz, S. (2009) Trends in the North Atlantic Carbon Sink: 19922006. Global Biogeochemical Cycles, 23, GB4011. http://dx.doi.org/10.1029/2008GB003383 
[10] Dutkiewicz, S., Follows, M.J. and Parekh, P. (2005) Interactions of the Iron Andphosphorus Cycles: A Three-Dimensional Model Study. Global Biogeochemical Cycles, 19, GB1021. http://dx.doi.org/10.1029/2004GB002342

[11] Omstedt, A., Gustafsson, E. and Wesslander, K. (2009) Modelling the Uptake and Release of Carbon Dioxide in the Baltic Sea Surface Water. Continental Shelf Research, 29, 870-885. http://dx.doi.org/10.1016/j.csr.2009.01.006

[12] Belyaev, K.P., Tanajura, C.A.S. and O’Brien, J.J. (2001) A Data Assimilation Method Used with an Ocean Circulation Model and Its Application to the Tropical Atlantic Ocean. Applied Mathematical Modelling, 25, 655-670. http://dx.doi.org/10.1016/S0307-904X(01)00003-8

[13] Natvik, L. and Evensen, G. (2003) Assimilation of Ocean Colour Data into a Biochemicalmodel of the North Atlantic_-Part 1 Data Assimilation Experiments. Journal of Marine Systems, 40, 127-153. http://dx.doi.org/10.1016/S0924-7963(03)00016-2

[14] Testut, C.-E., Brasseur, P., Brankart, J.-M. and Verron, J. (2003) Assimilation of Sea Surface Temperature and Altimetric Observations during 1992-1993 into an Eddy Permitting Primitive Equation Model of the North Atlantic Ocean. Journal of Marine Systems, 40-41, 291-316. http://dx.doi.org/10.1016/S0924-7963(03)00022-8

[15] McKinley, G.A., Takahashi, T., Buitenhius, E., Chai, F., Christian, J.F., Doney, S.C., LeQuere, C., Lima, I., Murtugudde, R., Shi, L. and Wetzel, P. (2006) North Pacific Carbon Cycle Response to Climate Variability on Seasonal to Decadal Timescales. Journal of Geophysical Research, 111, Article ID: C07S06. http://dx.doi.org/10.1029/2005JC003173

[16] Körtzinger, A., Send, U., Lampitt, R.S., Hartman, S., Wallace, D.W.R., Karstensen, J., Villagarcia, M.G., Llinas, O. and DeGrandpre, M.D. (2008) Seasonal $p \mathrm{CO}_{2}$ Cycle at $49^{\circ} \mathrm{N} / 16.5^{\circ} \mathrm{W}$ in the Northeast Atlantic Ocean and What It Tells Us about Biological Productivity. Journal of Geophysical Research, 113, Article ID: C04020. http://dx.doi.org/10.1029/2007JC004347

[17] Körtzinger, A., Send, U., Wallace, D.W.R., Kartensen, J. and DeGrandpre, M. (2008) Seasonal Cycle of $\mathrm{O}_{2}$ and $p \mathrm{CO}_{2}$ in the Central Labrador Sea: Atmospheric, Biological, and Physical Implications. Global Biogeochemical Cycles, 22, Article ID: GB1014. http://dx.doi.org/10.1029/2007GB003029

[18] Bennington, V., McKinley, G.A., Dutkiewicz, S. and Ullman, D. (2009) What Does Chlorophyll Variability Tell Us about Export and $\mathrm{CO}_{2}$ Flux Variability in North Atlantic? Global Biogeochemical Cycles, 23, Article ID: GB3002. http://dx.doi.org/10.1029/2008GB003241

[19] Reynolds, R.W., Smith, T.M., Liu, C., Chelton, D.B., Casey, K.S. and Schlax, M.G. (2007) Daily High-ResolutionBlended Analyses for Sea Surface Temperature. Journal of Climate, 20, 5473-5492.

[20] Gent, P.R. and McWilliams, J.C. (1990) Isopycnal Mixing in Ocean General Circulation Models. Journal of Physical Oceanography, 20, 150-155. http://dx.doi.org/10.1175/1520-0485(1990)020<0150:IMIOCM>2.0.CO;2

[21] Large, W.G., McWilliams, J.C. and Doney, S.C. (1994) Oceanic Vertical Mixing: A Review and a Model with a Nonlocal Boundary Layer Parameterization. Reviews of Geophysics, 32, 363-403. http://dx.doi.org/10.1029/94RG01872

[22] Follows, M.J., Dutkiewicz, S. and Ito, T. (2006) On the Solution of the Carbonate System in Ocean Biogeochemistry Models. Ocean Modeling, 12, 290-301. http://dx.doi.org/10.1016/j.ocemod.2005.05.004

[23] Keeling, C.D. and Whorf, T.P. (2005) Atmospheric $\mathrm{CO}_{2}$ Records from Sites in the SIO Airsampling Network. Trends: A Compendium of Data on Global Change. Carbon Dioxide Information Analysis Center, Oak Ridge National Laboratory, U.S. Department of Energy, Oak Ridge.

[24] Straneo, F. (2006) Heat and Freshwater Transport through the Central Labrador Sea. Journal of Physical Oceanography, 36, 606-628. http://dx.doi.org/10.1175/JPO2875.1

[25] Polonsky, A.B. (2008) Mixed Layer. In: Philanders, S.G., Ed., Encyclopedia of Global Warming and Climate Change, Vol. 2, Sage Publications Inc., Thousand Oaks, 657-658. http://dx.doi.org/10.4135/9781412963893.n428

[26] Kidston, M., Matear, R. and Baird, M.E. (2011) Parameter Optimisation of a Marine Ecosystem Model at Two Contrasting Stations in the Sub-Antarctic Zone. Deep Sea Research Part II: Topical Studies in Oceanography, 58, 23012315. http://dx.doi.org/10.1016/j.dsr2.2011.05.018

[27] Matear, R., Lenton, A., Chamberlain, M., Mongin, M. and Baird, M. (2013) Biogeochemical Modeling and Data Assimilation: Status in Australia and Internationally. Australian Coastal and Oceans Modelling and Observations Workshop (ACOMO) Extended Abstracts. http://imos.org.au/fileadmin/user_upload/shared/IMOS\%20General/ACOMO/Extended_Abstracts/15.MATEAR_Biog eochemical_modelling_and_data_assimilation_status_in_Australia_and_internationally.pdf

[28] Schartau, M. and Oschlies, A. (2003) Simultaneous Data-Based Optimization of a 1D-Ecosystem Model at Three Locations in the North Atlantic: Part I-Method and Parameter Estimates. Journal of Marine Research, 61, 765-793. http://dx.doi.org/10.1357/002224003322981147 
Scientific Research Publishing (SCIRP) is one of the largest Open Access journal publishers. It is currently publishing more than 200 open access, online, peer-reviewed journals covering a wide range of academic disciplines. SCIRP serves the worldwide academic communities and contributes to the progress and application of science with its publication.

Other selected journals from SCIRP are listed as below. Submit your manuscript to us via either submit@scirp.org or Online Submission Portal.
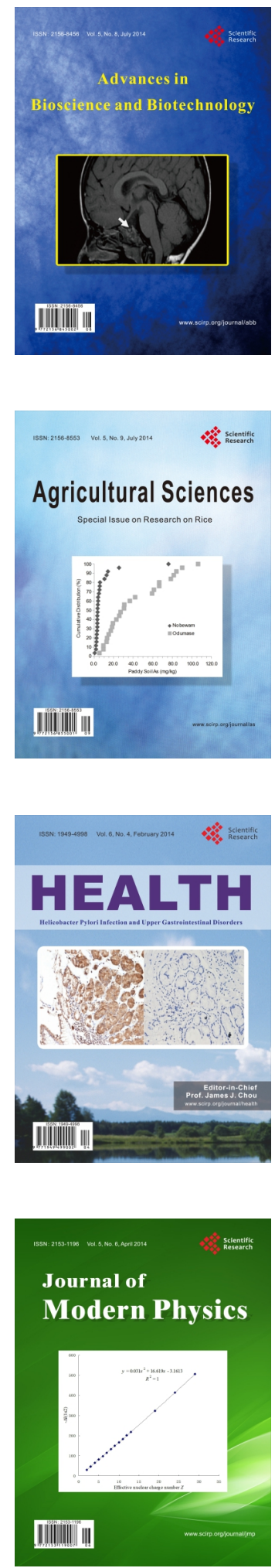
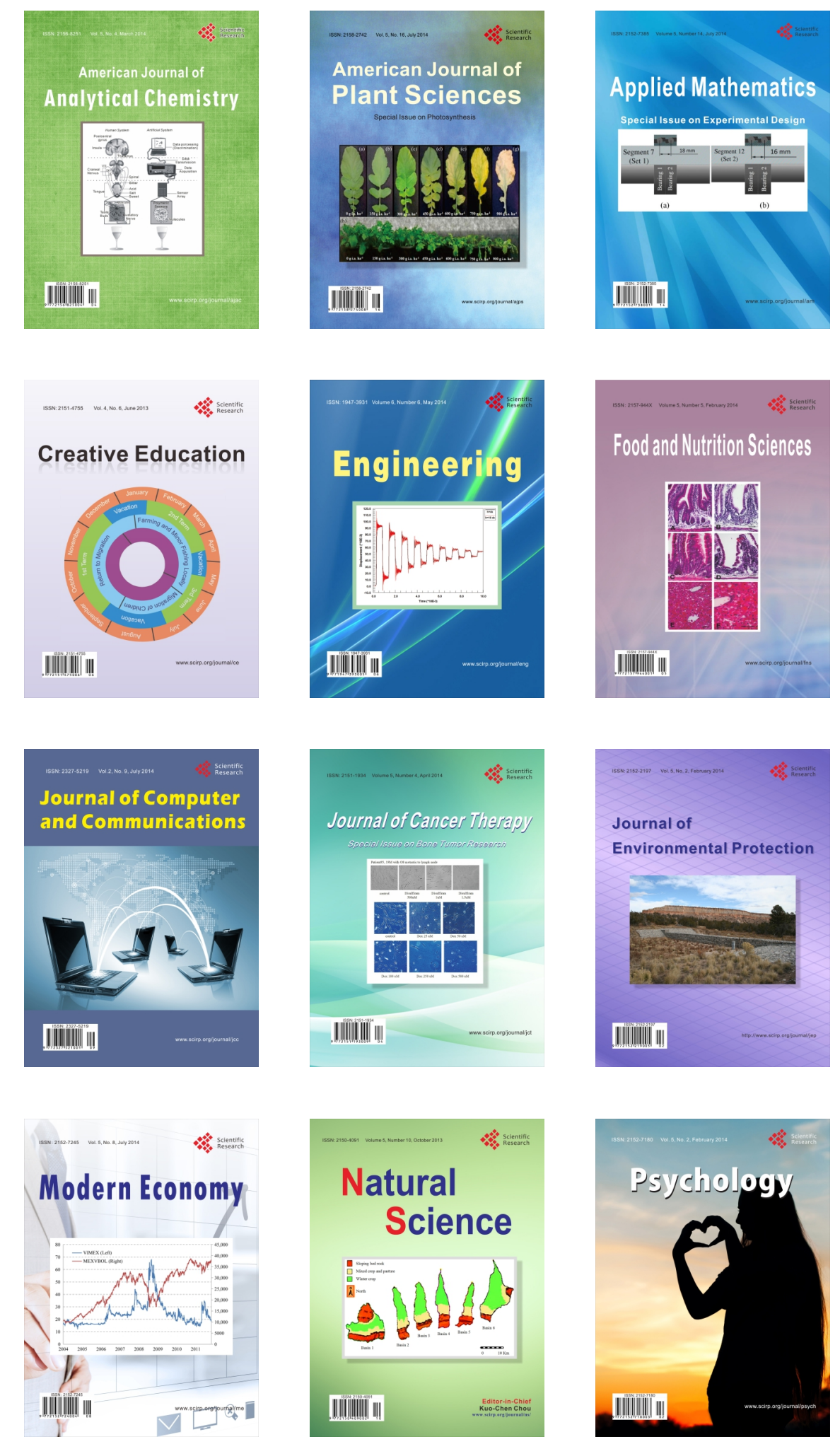